\title{
Pobreza no Brasil contemporâneo e formas de seu enfrentamento ${ }^{*}$
}

Poverty in Brazil in the contemporary time and ways to confront it

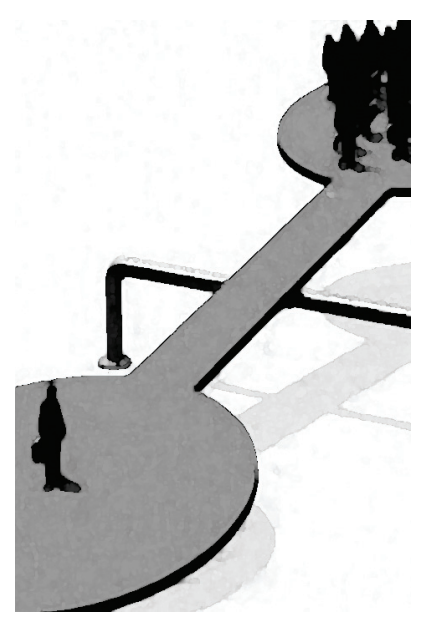

Maria Carmelita Yazbek*

Resumo: Este artigo desenvolve análise acerca da pobreza brasileira, com ênfase nas formas historicamente desenvolvidas para seu enfrentamento. Parte de uma concepção de pobreza como fenômeno complexo e multidimensional, situando-a como expressão de relações vigentes na sociedade. Apresenta ainda uma rápida caracterização de iniciativas históricas constituídas na perspectiva de seu enfrentamento.

Palavras-chave: Pobreza. Políticas sociais.

\begin{abstract}
This article presents an analysis of the Brazilian poverty, emphasizing historically developed ways to confront it. It starts from a conception of poverty taken as a complex and multidimensional phenomenon perceived as an expression of the relations current in the society. It also presents a brief characterization of initiatives historically constituted to confront it.
\end{abstract}

Keywords: Poverty. Social Policies

* Este texto incorpora e atualiza parte do artigo "A pobreza e as formas históricas de seu enfrentamento", Revista de Políticas Públicas Programa de Pós-Graduação em Políticas Públicas da UFMA, São Luís, v. 9, n. 1, jan./jun. 2005.

** Mestrado e doutorado em Serviço Social, docente e pesquisadora do Programa de Pós-graduação em Serviço Social, Pontifícia Universidade Católica de São Paulo, Brasil; pesquisadora 1A do CNPq. E-mail:mcyaz@uol.com.br 


\title{
Introdução conceitual e histórica
}

\begin{abstract}
O entendimento é de que o sistema de produção capitalista, centrado na expropriação e na exploração para garantir a mais-valia, e a repartição injusta e desigual da renda nacional entre as classes sociais são responsáveis pela instituição de um processo excludente, gerador e reprodutor da pobreza, entendida enquanto fenômeno estrutural, complexo, de natureza multidimensional, relativo, não podendo ser considerado como mera insuficiência de renda é também desigualdade na distribuição da riqueza socialmente produzida; é não acesso a serviços básicos; à informação; ao trabalho e a uma renda digna; é não a participação social e política.
\end{abstract}

Maria Ozanira da Silva e Silva (2010)

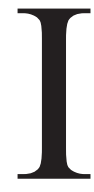

niciando a análise desta temática, gostaria de explicitar a concepção de pobreza que vem orientando minhas pesquisas e particularmente orienta estas reflexões. Assim, abordo a pobreza como uma das manifestações da questão social, ${ }^{1}$ e dessa forma como expressão direta das relações vigentes na sociedade, localizando a questão no âmbito de relações constitutivas de um padrão de desenvolvimento capitalista, extremamente desigual, em que convivem acumulação e miséria. Os "pobres" são produtos dessas relações, que produzem e reproduzem a desigualdade no plano social, político, econômico e cultural, definindo para eles um lugar na sociedade. Um lugar onde são desqualificados por suas crenças, seu modo de se expressar e seu comportamento social, sinais de "qualidades negativas" e indesejáveis que lhes são conferidas por sua procedência de classe, por sua condição social. Este lugar tem contornos ligados à própria trama social que gera a desigualdade e que se expressa não apenas em circunstâncias econômicas, sociais e políticas, mas também nos valores culturais das classes subalternas e de seus interlocutores na vida social. Assim sendo, a

1. A questão social resulta da divisão da sociedade em classes e da disputa pela riqueza socialmente gerada, cuja apropriação é extremamente desigual no capitalismo. Supõe, desse modo, a consciência da desigualdade e a resistência à opressão por parte dos que vivem de seu trabalho. Nos anos recentes, a questão social assume novas configurações e expressões, e "as necessidades sociais das maiorias, as lutas dos trabalhadores organizados pelo reconhecimento de seus direitos e suas refrações nas políticas públicas, arenas privilegiadas do exercício da profissão" sofrem a influência do neoliberalismo, em favor da economia política do capital." (Iamamoto, 2008, p.107) 
pobreza, expressão direta das relações sociais, "certamente não se reduz às privações materiais" (Yazbek, 2009, p. 73-74). É uma categoria multidimensional, e, portanto, não se caracteriza apenas pelo não acesso a bens, mas é categoria política que se traduz pela carência de direitos, de oportunidades, de informações, de possibilidades e de esperanças (Martins, 1991, p. 15).

Estamos nos referindo a uma forma de inserção na vida social, a uma condição de classe e, portanto, abordamos a pobreza como categoria histórica e socialmente construída, como fenômeno que não pode ser tomado como natural. Estamos também nos reportando à qualidade relativa da pobreza, que gira em torno da desigualdade social, assim como a outras condições reiteradoras da desigualdade (como gênero, etnia, procedência e outros aspectos). Como sabemos no Brasil, "a pobreza decorre em grande parte, de um quadro de extrema desigualdade, marcado por profunda concentração de renda. Essa situação coloca o Brasil entre os países de maior concentração de renda do mundo (Silva, 2010, p. 156).

A pobreza é parte de nossa experiência diária. Os impactos destrutivos das transformações em andamento no capitalismo contemporâneo vão deixando suas marcas sobre a população empobrecida: o aviltamento do trabalho, o desemprego, os empregados de modo precário e intermitente, os que se tornaram não empregáveis e supérfluos, a debilidade da saúde, o desconforto da moradia precária e insalubre, a alimentação insuficiente, a fome, a fadiga, a ignorância, a resignação, a revolta, a tensão e o medo são sinais que muitas vezes anunciam os limites da condição de vida dos excluídos e subalternizados na sociedade. Sinais que expressam também o quanto a sociedade pode tolerar a pobreza e banalizá-la e, sobretudo, a profunda incompatibilidade entre os ajustes estruturais da economia à nova ordem capitalista internacional e os investimentos sociais do Estado brasileiro. Incompatibilidade legitimada pelo discurso, pela política e pela sociabilidade engendrados no pensamento neoliberal, que, reconhecendo o dever moral de prestar socorro aos pobres e "inadaptados" à vida social, não reconhece seus direitos sociais (cf. Yazbek, 2009, p. 72).

A noção de pobreza ${ }^{2}$ é, portanto ampla e supõe gradações e embora seja "uma concepção relativa, dada a pluralidade de situações que comporta. Usual-

2. Do ponto de vista conceitual as abordagens sobre a pobreza podem ser construídas de diversas formas: 1) a partir de diferentes fundamentos teórico metodológicos: positivistas (funcionalistas, estruturalistas) marxistas; 2) do ponto de vista do desenvolvimento histórico social e político da sociedade capitalista: do 
mente vem sendo medida por meio de indicadores de renda e emprego, ao lado do usufruto de recursos sociais que interferem na determinação do padrão de vida, tais como saúde, educação, transporte, moradia, aposentadoria e pensões, entre outros. Os critérios, ainda que não homogêneos e marcados pela dimensão de renda, acabam por convergir na definição de que são pobres aqueles que, de modo temporário ou permanente, não têm acesso a um mínimo de bens e recursos, sendo, portanto, excluídos, em graus diferenciados, da riqueza social. Entre eles estão: os privados de meios de prover à sua própria subsistência e que não têm possibilidades de sobreviver sem ajuda; os trabalhadores assalariados ou por conta própria, que estão incluídos nas faixas mais baixas de renda; os desempregados e subempregados que fazem parte de uma vastíssima reserva de mão de obra que, possivelmente não será absorvida" (Yazbek, 2009, p. 73-74). ${ }^{3}$

Para Sposati (1996) é inviável o enfrentamento das condições de pobreza sem mudanças estruturais no modelo econômico concentrador, embora a inserção da questão na agenda pública brasileira, em meados da década de 1990, represente um avanço.

Do ponto de vista político, a questão se coloca pelas "lacunas de uma cidadania construída de forma segmentada, adjetivada, compartimentalizada,

\footnotetext{
Estado liberal (prevalência do mercado) ao Estado social (diretos sociais); 3) do ponto de vista da definição de indicadores, as medidas da pobreza podem ser monetárias, quando utilizam a renda como principal determinante da linha de pobreza e podem recorrer a indicadores multidimensionais, que incluem atributos não monetários para definir a pobreza, como o IDH, e o índice Gini. Esses indicadores multidimensionais incluem aspectos que afetam o bem-estar dos indivíduos e a não satisfação de suas necessidades básicas. Consideram como essencial para definir a condição de pobreza o acesso a alguns bens, de modo que sem esses os "cidadãos" não são capazes de usufruír uma vida minimamente digna. Incluem: água potável, rede de esgoto, coleta de lixo, acesso ao transporte coletivo, educação, saúde e moradia. O caráter multidimensional da pobreza leva á necessidade de indicadores que tenham uma correspondente abordagem multidimensional e que levem em consideração como o indivíduo percebe sua situação social.

Entre as abordagens multidimensionais destaca-se o pensamento de Amartya Sen, que enfoca a pobreza não apenas como baixo nível de renda, mas como privação de capacidades básicas, o que envolve acesso a bens e serviços. Para ele, o desenvolvimento seria resultado não apenas do crescimento econômico, mas "na eliminação das privações de liberdade e na criação de oportunidades" (Sen, 2000, p. 10).

3. Conforme Silva (2010, p. 157). Nessa direção, "categorias como classes sociais, exercito industrial de reserva, lumpem/proletariado, exploração e desigualdade são profícuas para explicar a pobreza na contemporaneidade". Para Marx, é lei geral da acumulação capitalista a substituição da força de trabalho por maquinaria e meios de produção, o que leva à subsunção real do trabalho ao capital, expulsando trabalhadores do mercado formal e constituindo um exército industrial de reserva.
} 
segundo a posição social, política e econômica dos sujeitos" (Araújo, 2009, p. 52) pela "não cidadania' (Fleury, 1994) ou pela construção tardia de direitos sociais na sociedade brasileira. ${ }^{4}$

Abordar aqueles que socialmente são constituídos como pobres é penetrar num universo de dimensões insuspeitadas. Universo marcado pela subalternidade, pela revolta silenciosa, pela humilhação e fadiga, pela crença na felicidade das gerações futuras, pela alienação e resistência e, sobretudo pelas estratégias para melhor sobreviver, apesar de tudo. Embora a renda se configure como elemento essencial para a identificação da pobreza, o acesso a bens, recursos e serviços sociais, ao lado de outros meios complementares de sobrevivência, precisa ser considerado para definir situações de pobreza.

Os pobres "nomeação da impotência sociológica para não designá-los como o vaivém entre o lúmpen e a fração estagnada do proletariado" (Oliveira, 2006), esta imensa parcela de humanidade de "gente explorada, enganada, iludida, massacrada, gente andarilhando por aí, à procura de um sítio onde parar, trabalhar, descansar o corpo, dormir, sobreviver" (Freire, 1988, p. 7). Gente que fica à espera em longas filas "para receber os benefícios: uma cesta "um saco de leite, uma consulta, um lugar no ônibus para ir ou voltar do trabalho, para obter um documento, para conseguir um emprego, reivindicar um direito"...

Outro aspecto que merece destaque refere-se à profunda estigmatização a que são submetidos os pobres, "[...] submersos numa ordem social que os desqualifica, marcados por clichês: 'inadaptados', 'marginais', 'problematizados', portadores de altos riscos, casos sociais, alvo de pedagogias de reerguimento e promoção (Verdes-Leroux, 1986), os pobres representam a herança histórica da estruturação econômica, política e social da sociedade brasileira" (cf. Yazbek, 2009, p. 22). Para Zaluar (1985, p. 35), sobre eles vem recaindo "grande parte da culpa pela ausência de mudanças significativas" nas sociedades em desenvolvimento. Para Sarti (2003, p. 36), o que se observa é a anulação do pobre como sujeito, e para Telles $(1992$, p. 3) a pobreza é traçada como uma realidade em negativo, uma espécie de limbo para a onde são projetadas as carências, as precariedades, as menoridades e os atrasos do país.

Sob outro jogo de referências, Giorgio Agamben (2002) oferece um princípio de intelegibilidade ao trabalhar com a noção de Estado de Exceção para

4. Sobre o processo de construção de direitos no Brasil, ler, $O$ direito social e a assistência social na sociedade brasileira: uma equação possível? São Paulo: Cortez, 2004. 
compor sua explicação sobre o mundo que vem se desenhando desde o final do século XX. Nessa referência, a exceção torna-se regra e saber "sobreviver na adversidade" e transitar entre fronteiras (em uma trama de ilegalidades) "pode decidir a vida e os sentidos da vida, escapando dessa dura partida entre a morte matada e a desfiguração da vida para aqueles que viram 'pobres de tudo' e se transformam em público-alvo dos programas sociais ditos de inserção, que nas palavras de Chico de Oliveira, não são mais do que a administração da exceção" (Telles, 2007, p. 217).

A dominação e a subalternidade fazem parte dessa pobreza. Tornar os indivíduos governáveis é parte do jogo. É Satriani (1986, p. 96) que nos recorda que o mundo dos dominados e o mundo dos dominadores não se encontram monoliticamente contrapostos, mas têm pontos de contato, exatamente aqueles onde o domínio se exerce. Do ponto de vista cultural, são realidades que se interpenetram sem linhas rígidas de demarcação, mas de qualquer modo é possível observar nelas que as ações e representações das classes subalternas correspondem a uma realidade caracterizada pelo lugar que ocupam na trama de relações sociais. De acordo com Telles (2007, p. 214-215) é nesse âmbito que se constrói um mundo social marcado pela "gestão das populações, gestão das vidas... e administração de suas urgências." Mas acontece que para a autora, esse mundo não cabe nos dispositivos gestionários, escapa por todos os lados. Não se trata apenas de a miséria ser grande demais para ser domesticada e capturada pela gestão do social. "É que esse mundo é tão incerto e a aleatoriedade da vida é tão devastadora que termina por implodir qualquer medida na ordem das coisas... quer dizer, os dispositivos gestionários e a vida matável fazem parte do mesmo jogo."

Na contemporaneidade, é bom lembrar ainda que a pobreza é uma face do descarte de mão de obra barata, que faz parte da expansão capitalista. Expansão na qual o trabalho, fonte da riqueza social, sofre os efeitos devastadores das mudanças que vem ocorrendo no processo de acumulação, com a reestruturação produtiva e com "financeirização" do capital em andamento nas últimas décadas. Expansão que cria uma população de trabalhadores precarizados, gente que se tornou não empregável, parcelas crescentes de trabalhadores que não encontram um lugar reconhecido na sociedade, que transitam à margem do trabalho e das formas de troca socialmente reconhecidas (Telles, 1998). Expansão que cria o necessitado, o desamparado e a tensão permanente da instabilidade e da insegurança no trabalho. Implica a disseminação do desemprego de longa duração, 
do trabalho precário, instável e intermitente, dos biscates e de outras modalidades de relacionamento da força de trabalho com o capital, que em sua essência representam uma mesma ordenação da vida social.

Nesse processo, que foi impulsionado pelas agências multilaterais e "teve como suporte as instituições financeiras que passaram a operar com o capital que rende juros (bancos, companhias de seguro, fundos de pensão, fundos mútuos e sociedades financeiras de investimento), o capital financeiro assumiu o comando do processo de acumulação envolvendo a economia e a sociedade, a política e a cultura, marcando profundamente as formas de sociabilidade e o jogo das forças sociais (cf. Iamamoto, 2007, p. 107).

A pobreza tem sido parte constitutiva da história do Brasil, assim como os sempre insuficientes recursos e serviços voltados para seu enfrentamento. Nessa história, não se pode esquecer o peso da "tradição oligárquica e autoritária, na qual os direitos nunca foram reconhecidos como parâmetros no ordenamento econômico e político da sociedade". Estamos nos referindo a uma sociedade desde sempre desigual e "dividida entre enclaves de 'modernidade' e uma maioria sem lugar", uma sociedade de extremas desigualdades e assimetrias. "Um país caracterizado por uma história regida por um privatismo selvagem e predatório, que faz da vontade privada e da defesa de privilégios a medida de todas as coisas, que recusa a alteridade e obstrui, por isso mesmo, a dimensão ética da vida social, pela recusa dos fundamentos da responsabilidade pública e da obrigação social" (Telles, 1993, p. 2-4).

Não é objetivo deste texto retomar iniciativas históricas de enfrentamento à pobreza na sociedade brasileira, mas é interessante uma rápida caracterização do percurso dessas ações, suas persistências e redefinições, sempre com definições da pobreza que não constroem a figura do cidadão, "mas sim a figura do pobre: figura desenhada em negativo, pela sua própria carência" (Telles, 1999, p. 190).

Sabemos que de modo geral o padrão de desenvolvimento do sistema de proteção social brasileiro, assim como dos países latino-americanos, foi bem diverso daquele observado nos países europeus, pois as peculiaridades da sociedade brasileira, de sua formação histórica e de suas dificuldades em adiar permanentemente a modernidade democrática, pesaram forte nesse processo. Assim sendo, o acesso a bens e serviços sociais caracterizou-se por ser desigual, heterogêneo e fragmentado. 
No caso brasileiro, a experiência colonial e a escravidão prolongada colocaram historicamente, para os trabalhadores, a responsabilidade por sua própria sobrevivência. Desse modo, até fins do século XIX, ganharam corpo obras sociais e filantrópicas, ações de ordens religiosas e redes de solidariedade e familiares (famílias extensas de vários tipos) que deram lugar a práticas sociais ligadas à sobrevivência sem o recurso ao "mercado".5

É na vila de São Paulo, por volta de 1560, que emerge a primeira instituição de atendimento à pobreza do país, a Irmandade de Misericórdia, que, apoiada em práticas de esmola, de inspiração portuguesa, ofertava dotes para órfãos e providenciava caixões para os mortos. Instalou-se em São Paulo “com uma pequena enfermaria que era ao mesmo tempo albergue e hospital, atendendo com alimentação, abrigo e enfermagem a escravos e homens livres, visto que não havia ainda médicos no país" (Mestriner, 2001, p. 40).

Este modelo vai ampliar-se nos séculos seguintes com a ação de outras ordens religiosas (franciscanos, beneditinos, carmelitas e vicentinos), que ofereciam refeições, abrigo, ajuda material e espiritual a pobres, órfãos, loucos e enfermos. Nesse processo, a Igreja católica tem importante papel, por meio de suas irmandades. As esmolas, que eram oficialmente recolhidas, e ações de caridade vão cunhar um modelo caritativo de assistência que recolhia dos ricos e distribuía aos pobres e que mesclava assistência e repressão. Assim, esmola foi a primeira modalidade de assistência social aos pobres no Brasil colonial, seguida da criação de instituições asilares e tutelares.

A Santa Casa, que inicia sua ação com serviços ambulatoriais e hospitalares, gradativamente cria novos serviços, com destaque para a solução asilar, entre os quais se destacam o "lazareto" (hospital para hansenianos) em 1802, a roda dos expostos em 1825; o asilo para inválidos e assistência a alienados e inválidos. "Crianças órfãs, leprosos, alienados, doentes e inválidos foram os primeiros segmentos que receberam uma forma assistencial institucionalizada" (Sposati, 1988, p. 78).

Em São Paulo, a Câmara era obrigada a destinar um sexto de seus recursos aos órfãos e é de sua iniciativa a proposta à Irmandade de Misericórdia de confinar os mendigos em 1874. Com relação às ações de enfrentamento à pobreza, a Câmara Municipal realizava inspeções por meio de comissões que

5. A respeito, ver Costa, 1990 e Wanderley, 2008. 
visitavam estabelecimentos de caridade e prisões. A postura (cf. Sposati, 1988) é fiscalizadora e confunde o atendimento à pobreza com práticas sanitárias. Essas ações serão a base para a caracterização de um atendimento aos pobres filantropizado e higienista na cidade em seu período colonial e imperial.

Esse modelo vai sofrer alterações com a expansão da economia pela exportação do café, configurando "a passagem da economia mercantil escravista para a economia exportadora capitalista, que caracteriza o Brasil no final do Império e nos primeiros anos da Velha República" (Sposati, 1988, p. 87).

No início do século XX, a pobreza é vista como incapacidade pessoal e objeto da benemerência e da filantropia. Aos poucos, com o desenvolvimento da urbanização e com a emergência da classe operária e de suas reivindicações e mobilizações, que se expandem a partir dos anos 1930, nos espaços das cidades, a "questão social" passa a ser o fator impulsionador de medidas estatais de proteção ao trabalhador e sua família. Nesse sentido, a questão social é expressão do processo de "formação e desenvolvimento da classe operária e de seu ingresso no cenário político da sociedade, exigindo seu reconhecimento como classe por parte do empresariado e do Estado" (Iamamoto, 1995, p. 77).

Ao reconhecer a legitimidade da questão social, no âmbito das relações entre capital e trabalho, o governo Vargas busca enquadrá-la juridicamente, visando desmobilização da classe operária e a regulação das tensões entre as classes sociais mediante a Consolidação das Leis do Trabalho (CLT), o salário mínimo, a valorização da saúde do trabalhador e outras medidas de cunho controlador e paternalista. Como mostra Ianni (1990), o Estado brasileiro transformou a questão social em problema de administração, desenvolvendo políticas e agências de poder estatal nos mais diversos setores da vida nacional.

Em síntese, o Estado brasileiro, desenvolvendo acordos de interesse do capital e dos trabalhadores nos mais diversos setores da vida nacional, opta pela via do seguro social. O sistema de proteção nesse período é seletivo e distante de um padrão universalista. "Considerada legítima pelo Estado, a questão social circunscreve um terreno de disputa pelos bens socialmente construídos e está na base das primeiras políticas sociais no país. A partir do Estado Novo (Getúlio Vargas, 1937-45), as políticas sociais se desenvolvem de forma crescente, como resposta às necessidades do processo de industrialização" (Yazbek, 2008, p. 89-90). Para responder às pressões das novas forças sociais urbanas, o Estado desenvolve esforços reformadores e, nesse cenário, 
o sistema protetivo brasileiro se dualiza: de um lado, desenvolve-se fortemente, apoiado na capacidade contributiva dos trabalhadores, particularmente do mercado formal de trabalho, e de outro vai destinar aos mais pobres, trabalhadores de um mercado informal, um "modelo de regulação pela benemerência" (Sposati, 1994, p. 8).

Assim, pela legislação trabalhista, a classe trabalhadora tem garantidos alguns direitos básicos, como: a regulamentação da jornada de trabalho, o repouso remunerado, as férias, o trabalho feminino e dos "menores". ${ }^{6}$ Para o trabalhador pobre, sem carteira assinada ou desempregado, restam as obras sociais e filantrópicas que se mantêm por meio de uma rede burocrática e clientelista, fortemente apoiada pela filantropia e desenvolvida por meio de iniciativas institucionalizadas em organizações sem fins lucrativos. "O isolamento dos 'desajustados' em espaços educativos e corretivos constituía estratégia segura para a manutenção 'pacífica' da parte sadia da sociedade." (Adorno, 1990, p. 9) Portanto, o que se observa é que historicamente a proteção social brasileira vai se estruturando, parte vinculada à proteção ao trabalho formal e parte acoplada ao conjunto de iniciativas benemerentes e filantrópicas da sociedade civil.

A inserção seletiva no sistema protetivo, segundo de critérios de mérito, vai basear-se numa lógica de benemerência, dependente e caracterizada pela insuficiência e precariedade, moldando a cultura de que "para os pobres qualquer coisa basta". Dessa forma, o Estado não apenas incentiva a benemerência, mas passa a ser responsável por ela, regulando-a por meio do Conselho Nacional de Serviços Sociais - CNSS (criado em 1938), mantendo a atenção aos pobres sem a definição de uma política, não acompanhando os ganhos trabalhistas e previdenciários, restritos a poucas categorias (cf. Mestriner, 2001).

A partir de 1937, com a implantação da ditadura Vargas no país, o Estado (Estado Novo) amplia suas medidas de proteção ao trabalhador, ao mesmo tempo em que intervém no movimento sindical por meio de uma legislação que objetivava o controle rigoroso das organizações dos trabalhadores. Em 1945 o país volta ao regime democrático, conservando características do

6. Entre 1930 e 1937 são criadas instituições prestadoras de serviço sociais, como o Departamento de Assistência Social do Estado de São Paulo, subordinado à Secretaria de Justiça e Negócios Interiores, ao qual coube a estruturação dos Serviços Sociais de Menores, desvalidos, trabalhadores e egressos de reformatórios, penitenciárias e hospitais, e Consultoria Jurídica do Serviço Social. 
populismo do período ditatorial de Vargas (1937-45). Nesse quadro, verifica-se a emergência de novas forças sociais na vida nacional. Cresce a população urbana, formada pelo proletariado industrial e também por trabalhadores braçais não integrados ao setor industrial, empregados dos serviços públicos, operários de pequenas oficinas e do setor terciário, trabalhadores por conta própria, entre outros. Crescem pressões sobre o Estado para a ampliação de serviços sociais. ${ }^{7}$

Em 1942 o governo brasileiro criou a LBA para atender às famílias dos expedicionários brasileiros. Terminada a guerra, a LBA se volta para a assistência à maternidade e à infância, iniciando a política de convênios com instituições sociais no âmbito da filantropia e da benemerência. Caracterizada por ações paternalistas e de prestação de auxílios emergenciais e paliativos à miséria, vai interferir junto aos segmentos mais pobres da sociedade, mobilizando a sociedade civil e o trabalho feminino. Essa modalidade de intervenção está na raiz da relação simbiótica que a emergente assistência social brasileira vai estabelecer com a filantropia e com a benemerência (cf. Mestriner, 2001). ${ }^{8}$

Com o tempo, as velhas formas de socorrer os pobres gestadas na filantropia e na benemerência evoluem, passando desde "a arrecadação de fundos para a manutenção de instituições carentes, auxílio econômico, amparo e apoio à família, orientação maternal, campanhas de higiene, fornecimento de filtros, assistência médico-odontológica, manutenção de creches e orfanatos, lactários, concessão de instrumentos de trabalho etc.” até programas explicitamente anunciados, como de combate à pobreza. Assim, no âmbito da assistência social são desenvolvidas políticas para a infância e para a adolescência, para idosos, para necessitados e grupos vulneráveis.

O pobre, trabalhador eventual e destituído, é o usuário dessas políticas pelas quais é visto como "indivíduo necessitado", e muitas vezes como pessoa

7. É também nesse contexto que emerge como profissão o Serviço Social brasileiro marcado pelo projeto político da Igreja Católica, expresso "pela doutrina e pela ação social católica" que nesse momento histórico prioriza a ação social (intervenção direcionada para mudanças políticas e sociais sob a ótica da Doutrina Social da Igreja), em detrimento de ações de assistência social. Ainda assim, a assistência social era considerada um avanço em relação às práticas filantrópicas prevalecentes até então.

8. 10 Para a autora, "assistência social, filantropia e benemerência têm sido tratadas no Brasil como irmãs siamesas, substitutas umas da outras” (Mestriner, 2001, p. 14). 
acomodada, passiva em relação à sua própria condição, dependente de ajuda, enfim, não cidadão. Sua figura continua desenhada em negativo (cf. Telles, 1999).

A década de 1950 teve como característica o investimento estatal em políticas desenvolvimentistas e a busca do crescimento econômico. A intervenção planejada do Estado nos processos voltados ao desenvolvimento social e econômico impulsionou a criação e a expansão de novas empresas estatais. A ideologia desenvolvimentista apoiava-se na tese de que o atraso dos países do Terceiro Mundo era consequência de seu precário sistema industrial e de suas insuficiências tecnológicas. No contexto desenvolvimentista, as instituições sociais direcionavam seus programas para uma política de integração participativa dos mais pobres no processo de desenvolvimento nacional, e a pobreza era abordada como resultado de um insuficiente desenvolvimento econômico, do estágio ainda não suficientemente desenvolvido do país e, portanto, como fenômeno não estrutural.

O início da década de 1960 acirra as contradições do capitalismo periférico trazendo consigo o golpe militar e a instalação do Estado autoritário. A opção pelo crescimento econômico acelerado, a partir de fontes de investimento externas, como base do desenvolvimento, abriu o país ao capital monopolista. O Estado amplia seu nível de intervenção, tornando-se o eixo político da recomposição do poder burguês, com a implantação de novas estratégias de desenvolvimento concentradoras de capital, intensificando o nível de exploração da classe operária. A desigualdade social se acentua em um clima repressivo e autoritário.

Em síntese, com a expansão do capitalismo monopolista ocorrem mudanças, que vão se efetivar durante as décadas de 1960 e 1970, no sentido de expansão e modernização do sistema de proteção social do país. Trata-se de um processo de modernização conservadora, que vai combinar assistência à pobreza com repressão, pois essas mudanças não significaram uma ruptura com os padrões meritocráticos prevalecentes até então, mas nesse período, por exemplo, o INPS incorporou novos segurados, expandiu a assistência médica previdenciária e criou em 1974 a Renda Mensal Vitalícia (RMV) para idosos e inválidos com baixa renda. Ainda nessa época houve a criação de novos mecanismos de poupança compulsória por meio do Fundo de Garantia por Tempo de Serviço - FGTS e posteriormente o PIS/Pasep. Foram criados 
também o Programa de Assistência ao Trabalhador Rural (ProRural), o Sistema Financeiro de Habitação, os Centros Sociais Urbanos, o Programa de Interiorização de Ação de Saúde e Saneamento no Nordeste (Piass), o Programa de Financiamento de Lotes Urbanizados (Profilurb), entre outros, além do Ministério da Previdência e Assistência Social (MPAS), que incluiu no novo sistema a Legião Brasileira de Assistência — LBA e a Fundação Nacional de Bem-Estar do Menor - Funabem.

Cabe ainda ressaltar que a partir de meados de 1970 observa-se um avanço organizativo da sociedade civil, especialmente dos movimentos sociais na luta pela redemocratização e pela retomada do Estado democrático de direito. O movimento sindical se fortalece, crescentemente e aos poucos renascem organizações populares e associações comunitárias vinculadas a setores progressistas da Igreja Católica. Esses movimentos sociais demonstram um nível de consciência e capacidade de organização em comunidades eclesiais de base (CEBs), sindicatos, organizações profissionais liberais, meios universitários, Igreja e imprensa. Expressam-se em greves, reivindicações coletivas, movimentos contra a carestia, movimento por eleição direta para a Presidência da República, pelo respeito a direitos humanos, entre vários outros.

Nos anos 1980 (a década perdida para a Cepal), a pobreza vai se converter em tema central na agenda social, quer por sua crescente visibilidade, pois a década deixou um aumento considerável do número absoluto de pobres, quer pelas pressões de democratização que caracterizaram a transição. Tratava-se de uma conjuntura econômica dramática, dominada pela distância entre minorias abastadas e massas miseráveis. Permanecem as antinomias entre pobreza e cidadania. ${ }^{9}$

"Na esteira desse processo, as forças oposicionistas foram pontilhando uma extensa agenda política, econômica e social de mudanças. Na primeira

9. Nesse contexto, as agências multilaterais, atendendo à agenda neoliberal, assumem ações e políticas de enfrentamento à pobreza expressando-se em ações técnicas focalizadas, de caráter gerencialista e voltadas ao alívio da pobreza. Relatório do Banco Mundial (1990, p. 1) trata da pobreza no mundo em desenvolvimento, classificando-a a partir de indicadores econômicos, como a renda per capita. A proposta é "aliviar" a pobreza extrema por meio de programas assistenciais acompanhados de condicionalidades. No início da década de 2000, o Banco Mundial (2002) assume uma visão multidimensional da pobreza, incorporando os conceitos de vulnerabilidade e risco social. Os pobres passam a ser vistos como portadores de "ativos", devem ser "empoderados" e ter suas capacidades valorizadas (Sen, 2001). 
metade dos anos 1980, já era possível identificar os contornos de um amplo projeto de reforma de cunho nacional, democrático, desenvolvimentista e redistributivo" (Fagnani, 2005, p. 88).

Nesse contexto, a Assembleia Nacional Constituinte ${ }^{10}$ concentrou esforços no sentido de ampliar a intervenção social do Estado, garantindo e criando mecanismos de viabilização de direitos civis, políticos e sociais.

\section{As políticas sociais e o padrão protetivo que emerge com a constituição - 0 enfrentamento à pobreza nos anos recentes}

Como sabemos, com a Constituição de 1988 são colocadas novas bases para o atual Sistema de Proteção Social brasileiro com a definição da Seguridade Social e o reconhecimento de direitos sociais das classes subalternizadas em nossa sociedade.

Em seu artigo 194, a Constituição define a Seguridade Social como um "conjunto integrado de ações de iniciativa dos poderes públicos e da sociedade, destinadas a assegurar os direitos relativos à saúde, à previdência e à assistência social".

A noção de Seguridade que emerge na Constituição brasileira apresenta-a como um sistema de cobertura de diferentes contingências sociais que podem alcançar a população em seu ciclo de vida, sua trajetória laboral e em situações de renda insuficiente. Trata-se de uma cobertura social que não depende do custeio individual direto. São objetivos da Seguridade Social:

a universalidade de cobertura e de atendimento; uniformidade e equivalência dos benefícios e dos serviços às populações urbanas e rurais; seletividade e distributividade na prestação dos benefícios e serviços; irredutibilidade do valor dos benefícios; equidade na forma de participação no custeio; diversidade da base de financiamento; caráter democrático e descentralizado da administração, mediante gestão quadripartite, com a participação dos trabalhadores, dos empregadores, dos aposentados e do governo nos órgãos colegiados. (Parágrafo Único do artigo 194 da Constituição Federal)

10. Convocada pela EC n. 26, de 1985 e instalada no dia $1^{\circ}$ de fevereiro de 1987. 
Alguns aspectos devem ser destacados entre as inovações constitucionais em relação ao sistema protetivo brasileiro: a centralidade da responsabilidade do Estado na regulação, normatização, proposição e implementação das políticas públicas no âmbito da proteção social e a proposta de descentralização e participação da sociedade no controle das políticas sociais. A perspectiva de articular e integrar políticas também emerge nesse contexto. ${ }^{11}$ Para estudo do Ipea ${ }^{12}$ a Constituição de 1988 redesenha "de forma radical o sistema brasileiro de proteção social, afastando-o do modelo meritocrático-conservador e aproximando-o do modelo redistributivista, voltado para a proteção de toda a sociedade, dos riscos impostos pela economia de mercado".

É necessário, porém, ressaltar o fato de que a Constituição brasileira é promulgada em uma conjuntura dramática, dominada pelo crescimento da pobreza e da desigualdade social no país, que vê ampliar sua situação de endividamento (que cresce 61\% nos anos 1980), e que se insere em um momento histórico de ruptura do "pacto keynesiano", que vai permitir grande liberdade aos processos de reestruturação produtiva. A pressão do Consenso de Washington ${ }^{13}$, com sua proposição de que é preciso limitar a intervenção do Estado e realizar as reformas neoliberais, a presença dos organismos de Washington (FMI, Banco Mundial) responsáveis por estabelecer as estratégias para o enfrentamento da crise por parte dos países periféricos, e a redução da autonomia nacional, ao lado da adoção de medidas econômicas e do ajuste fiscal são características desse contexto, que, no campo da proteção social, vai se enfrentar com o crescimento dos índices de desemprego, pobreza e indigência. ${ }^{14}$

Ou seja, é na "contramão" das transformações que ocorrem na ordem econômica internacional, tensionado pela consolidação do modelo neoliberal,

11. Um exemplo dessa perspectiva é o parágrafo único do artigo $2^{\circ}$ da Loas — Lei n. 8.742 (Lei Orgânica da Assistência Social de 7 de dezembro de 1993) que afirma: "A assistência social realiza-se de forma integrada às políticas setoriais, visando ao enfrentamento da pobreza, à garantia dos mínimos sociais, ao provimento de condições para atender contingências sociais e à universalização dos direitos sociais."

12. Ver CASTRO e RIBEIRO, 2009.

13. Reunião realizada em novembro de 1989 entre os presidentes eleitos da América Latina e os representantes do Banco Mundial, Fundo Monetário Internacional e Banco Interamericano de Desenvolvimento, que, entre as reformas de cunho neoliberal, prevê a realização de reformas estruturais para a estabilização da economia como as privatizações, a desregulamentação dos mercados, a descentralização e a retomada do desenvolvimento.

14. É importante assinalar que essas políticas de ajuste fazem parte de um movimento global de reordenamento das relações capitalistas entre centro e periferia do sistema. 
pelas estratégias de mundialização e financeirização do capital, com a sua direção privatizadora e focalizadora das políticas sociais, enfrentando a "rearticulação do bloco conservador" com a eleição de Fernando Collor que busca de diversas formas obstruir a realização dos novos direitos constitucionais (cf. Ipea, 2009) que devemos situar o início do processo de construção da Seguridade Social brasileira. E, como não poderia deixar de ser, a emergente proposta de Seguridade Social não se consolida e mostra-se incapaz de, naquele momento, realizar suas promessas.

É sempre oportuno lembrar que, nos anos 1990 a somatória de extorsões que configurou um novo perfil para a questão social brasileira, particularmente pela via da vulnerabilização do trabalho, conviveu com a erosão do sistema público de proteção social, caracterizada por uma perspectiva de retração dos investimentos públicos no campo social, seu reordenamento e pela crescente subordinação das políticas sociais às políticas de ajuste da economia, com suas restrições aos gastos públicos e sua perspectiva privatizadora (cf. Yazbek, 2004).

É nesse contexto que tem início a construção de uma nova concepção para a Assistência Social brasileira, que é regulamentada em 1993, como política social pública, e inicia seu trânsito para um campo novo: o dos direitos, da universalização dos acessos e da responsabilidade estatal.

Nesse sentido, pode-se afirmar que a Constituição e a Lei Orgânica da Assistência Social — Loas estabelecem uma nova matriz para a Assistência Social no país, iniciando um processo que tem como perspectiva torná-la visível como política pública e direito dos que dela necessitarem. A inserção na Seguridade aponta também para seu caráter de política de proteção social, ${ }_{1}^{15}$

15. Cabe inicialmente assinalar que, de forma geral, não encontramos sociedades humanas que não tenham desenvolvido alguma forma de proteção aos seus membros mais vulneráveis. Cf. Giovanni (1998, p. 9) seja de modo rústico, por meio de instituições não especializadas e plurifuncionais, como a família por exemplo, ou com altos níveis de sofisticação organizacional e especialização, diferentes formas de proteção social emergem e percorrem o tempo e o espaço das sociedades "como processo recorrente e universal."

Para o autor, por proteção social entendem-se as formas "às vezes mais, às vezes menos institucionalizadas que as sociedades constituem para proteger parte ou o conjunto de seus membros. Tais sistemas decorrem de certas vicissitudes da vida natural ou social, tais como a velhice, a doença, o infortúnio, as privações. Incluo neste conceito, também tanto as formas seletivas de distribuição e redistribuição de bens materiais (como a comida e o dinheiro), quanto os bens culturais (como os saberes), que permitirão a sobrevivência e a integração, sob várias formas na vida social. Incluo, ainda, os princípios reguladores e as normas que, com o intuito de proteção, fazem parte da vida das coletividades” (Di Giovanni, 1998, p. 10). 
voltada para o enfrentamento da pobreza e articulada a outras políticas do campo social voltadas para a garantia de direitos e de condições dignas de vida.

Inovação é afirmar para a assistência social seu caráter de direito não contributivo, (independentemente de contribuição à Seguridade e para além dos interesses do mercado), ao apontar a necessária integração entre o econômico e o social e ao apresentar novo desenho institucional para a assistência social. Inova também ao propor a participação da população e o exercício do controle da sociedade na gestão e execução das políticas de assistência social. Tendência ambígua, de inspiração neoliberal, mas que contraditoriamente pode direcionar-se para os interesses de seus usuários. Sem dúvida, mudanças substantivas na concepção da assistência social, um avanço que permite sua passagem do assistencialismo e de sua tradição de não política para o campo da política pública.

Como política de Estado, passa a ser um espaço para a defesa e atenção dos interesses e necessidades sociais dos segmentos mais empobrecidos da sociedade, configurando-se também como estratégia fundamental no combate à pobreza, à discriminação e à subalternidade econômica, cultural e política em que vive grande parte da população brasileira. Assim, cabem à assistência social ações de prevenção e provimento de um conjunto de garantias ou seguranças (Sposati, 1995). Essas garantias se efetivam pela construção do que Mishra denomina de "rede de segurança da rede de Segurança", ou seja, um conjunto de programas, projetos, serviços e benefícios voltados para a proteção social e para o atendimento de necessidades da população usuária dessa política.

Em geral caracterizada por sua heterogeneidade, essa rede de segurança (constituída pelos órgãos governamentais e por entidades da sociedade civil) opera serviços voltados ao atendimento de um vastíssimo conjunto de necessidades particularmente dos segmentos mais pobres da sociedade.

Dessa forma a assistência social como campo de efetivação de direitos emerge como política estratégica, não contributiva, voltada para o enfrentamento da pobreza e para à construção e o provimento de mínimos sociais de inclusão ${ }^{16}$ e para a universalização de direitos, buscando romper com a tradição

16. Para Sposati (1997, p. 10, grifos da autora) "propor mínimos sociais é estabelecer o patamar de cobertura de riscos e de garantias que uma sociedade quer garantir para todos os seus cidadãos. Trata-se de definir o patamar de dignidade abaixo do qual nenhum cidadão deveria estar". 
clientelista e assistencialista que historicamente permeia a área onde sempre foi vista como prática secundária, em geral adstrita às atividades do plantão social, de atenções em emergências e distribuição de auxílios financeiros.

Cabe, no entanto, observar que se a Constituição Federal cria uma nova arquitetura institucional e ético/política para a proteção social brasileira, particularmente para a política de assistência social, pois esta é também objeto de esvaziamentos e desqualificações em seu processo de implantação pós-constitucional no país, contexto em que ocorre a despolitização e a refilantropização do enfrentamento da questão social brasileira. ${ }^{17}$

A busca da estabilização da economia e do equilíbrio orçamentário e fiscal a partir do Plano Real leva, no período dos governos de FHC (1995-98 e 1999-2002) a resultados pouco favoráveis para a proteção social na esfera pública estatal. O ambiente é de desacertos e tensões entre a adequação ao ambiente neoliberal e as reformas sociais exigidas constitucionalmente.

Conforme Fagnani (1999), a política econômica adotada não favoreceu o sucesso das políticas sociais. O autor cita como exemplo a política de emprego (insuficiente para reverter o quadro produzido pela política econômica) e o problema da Previdência Social (que viu sua base de financiamento erodir com o aumento da precarização e informalização da ocupação). No que se refere às políticas de saúde, educação e assistência social, Fagnani (1999, p. 166) aponta avanços no processo de descentralização, mas ressalta que "ao mesmo tempo em que estados e municípios são induzidos a aceitarem novas responsabilidades administrativas e financeiras na gestão das políticas sociais, a política econômica desorganiza as finanças destas instâncias [...]”.

É importante assinalar que essas ações emergem no país em um contexto de profundas transformações societárias, que interferem na "questão social" e

17. Outro aspecto relevante que compõe essa conjuntura é a perspectiva tecnocrática progressista das agências multilaterais (BID - Banco Interamericano de Desenvolvimento; Cepal - Comissão Econômica para a América Latina e o Caribe, e o PNUD - Programa das Nações Unidas para o Desenvolvimento) que operam pela subordinação e separação entre o plano econômico e social, na perspectiva de que a superação da pobreza é estratégia de desenvolvimento, que se efetiva "através de quatro pilares que estruturam e condicionam o novo modelo de assistência: um processo de desconstrução simbólica e ideológica dos sistemas de seguridade anteriores, em nível de retórica crítica; a centralidade do tratamento da inserção dos indivíduos ao mercado, através de transferências monetárias; o estímulo dos programas ao consumo e demanda de serviços e uma organização e mobilização da sociedade civil e dos próprios pobres na construção dos programas sociais" (Ivo,2006, p. 82). 
trazem na raiz dessas modificações a indagação sobre a compatibilidade (ou não) entre direitos, políticas sociais e as relações que se estabelecem entre Estado, sociedade e mercado nos novos marcos da acumulação capitalista. Contexto no qual a articulação: trabalho, direitos e proteção social pública sofre os impactos das transformações estruturais do capitalismo, que atingem duramente o trabalho assalariado e as relações de trabalho, levando à redefinição dos sistemas de proteção social e da política social em geral.

Apesar de eleger como prioridade absoluta o ajuste e a estabilidade econômica e dar pouca atenção à agenda social, a partir de 2001 o governo FHC tenta reverter esse quadro ao criar por meio, de um contrato com o BID, a "rede de proteção social". Esta "rede" introduziu no campo social de forma seletiva um conjunto de ações setoriais voltadas para os segmentos mais vulneráveis da população. Essas ações conjugavam serviços sociais e transferências monetárias, com destaque para a expansão do Programa de Erradicação do Trabalho Infantil — Peti, criado em 1996, para o Programa Nacional de Renda Mínima vinculado à Educação - Bolsa-Escola, o Programa Bolsa Alimentação, o Agente Jovem e um pouco mais tarde o Auxílio Gás (2002). ${ }^{18}$

Esse conjunto de programas federais, devido à sua abrangência e tamanho, permitiu o crescimento da relevância das propostas de transferências monetárias no âmbito da política social. Conforme estudo de Silva, Yazbek e Giovanni (2011), com a ampliação dos programas federais, os programas de iniciativa municipal e estadual aos poucos vão sofrendo alterações seguintes aspectos:

[...] desativação de programas já em implementação, principalmente em municípios que apresentam menores orçamentos. Nesses municípios, os programas vêm sendo substituídos pelo programa federal, bem como parece vir ocorrendo uma desaceleração de iniciativas para criação de novos programas, tanto por parte de Estados como de municípios, considerando que já implantaram programas similares federais; existência paralela de programas municipais, estaduais e federais, adotando benefícios com valores diferenciados; articulação do progra-

18. Os programas federais tiveram como precursores programas municipais e estaduais que tiveram início em 1995 com o Programa de Garantia de Renda Familiar Mínima da Prefeitura de Campinas (SP) e da Prefeitura de Ribeirão Preto (SP); o Programa Bolsa Escola em Brasília e o Programa "Nossa Família!" da Prefeitura de Santos (SP). Ver, a esse respeito, Silva, Giovanni e Yazbek, 2011, $5^{a}$ edição. 
ma Bolsa-Escola federal com similares municipais, mais especificamente, no caso de municípios que têm orçamentos mais elevados, como São Paulo, Porto Alegre e Belo Horizonte, com complementação do valor do benefício dos programas federais com recursos do município, entre outros. (Silva, Yazbek e Giovanni, 2011, p. 157)

Com o governo Lula (2003-06) a questão social, e particularmente o enfrentamento da pobreza, passa a ser alvo de novas abordagens. $\mathrm{O}$ combate à fome e à miséria, expresso no início do primeiro governo Lula pelo emblemático Programa Fome Zero, cujo "Cartão Alimentação" teve seu lançamento simbólico no dia 3 de fevereiro de 2003 nos municípios de Acauã e Guaribas no Piaú, com a distribuição de cartões para quinhentas famílias. ${ }^{19}$

Ainda em 2003 o "Cartão Alimentação" foi unificado ao Programa Bolsa Família, ${ }^{20}$ o que significou um importante passo na busca de articulação do sistema protetivo no país. O Programa Bolsa Família (20/10/2003) resultou da unificação de quatro programas federais: Bolsa Escola, Bolsa Alimentação, Vale Gás e Cartão Alimentação. Apresentou como objetivos:

a) Combater a fome, a pobreza e as desigualdades por meio da transferência de um benefício financeiro associado à garantia do acesso aos direitos sociais básicos — saúde, educação, assistência social e segurança alimentar.

b) Promover a inclusão social, contribuindo para a emancipação das famílias beneficiárias, construindo meios e condições para que elas possam sair da situação de vulnerabilidade em que se encontram (Brasil/MDS, 2006).

19. Uma avaliação inicial do Programa Fome Zero mostra tratar-se de proposta no âmbito da segurança alimentar, que busca contribuir para que a sociedade brasileira caminhe na efetivação do direito humano à segurança alimentar e nutricional. A relação entre o emergencial e o permanente presente em todo o texto do Projeto, em diferentes perspectivas temporais com propostas de curto, médio e longo prazo, é sem dúvida um dos aspectos mais relevantes do mesmo. Cabe ressaltar, porém, que a proposta inicial apresentava lacunas, em especial na problematização dos fundamentos estruturais da desigualdade social que historicamente caracteriza a sociedade brasileira e ao não levar em consideração outros programas sociais no âmbito do enfrentamento à pobreza, particularmente as políticas de Seguridade Social, conforme propõe a Constituição Federal de 1988 (cf. Yazbek, 2004).

20. A questão da unificação dos Programas de Transferência de Renda foi colocada a partir de diagnóstico sobre os programas sociais em desenvolvimento no país, elaborado na transição do governo FHC para o governo Lula no terceiro trimestre de 2002. 
Assim sendo, a unificação dos programas de transferência de renda situa-se no âmbito da prioridade de combate à fome e à pobreza, representando uma perspectiva de articulação entre níveis de governo e de políticas sociais.

Da mesma forma, a criação do Ministério do Desenvolvimento Social e Combate à Fome em 2004 que unificou a política de combate à fome com as políticas de transferência de renda e de assistência social, foi um passo significativo na direção de articular um conjunto de iniciativas na perspectiva do enfrentamento à pobreza no país.

\section{0 Programa Bolsa Família}

O Programa Bolsa Família, criado em 2003 pelo governo federal, é considerado um eixo estratégico para a integração de políticas e ações no enfrentamento da pobreza, no acesso à educação e no combate ao trabalho infantil. Foi criado tendo como perspectiva unificar os programas de transferência de renda em vigência no âmbito federal, a partir da constatação de seu funcionamento com programas concorrentes e sobrepostos nos seus objetivos e no seu público-alvo; da ausência de uma coordenação geral desses programas, gerando desperdício de recursos; da ausência de planejamento gerencial dos mesmos e dispersão de comando em diversos ministérios, além de orçamentos alocados insuficientes e do não alcance do público-alvo conforme os critérios de elegibilidade dos programas. Foram unificados: o Bolsa Escola, o Bolsa Alimentação, o Auxílio Gás, o Cartão Alimentação, o Programa de Erradicação do Trabalho Infantil - Peti e o Agente Jovem.

Tendo como perspectiva a articulação da transferência monetária e políticas educacionais, de saúde e de trabalho direcionadas a crianças, jovens e adultos de famílias pobres, o programa partiu de

dois pressupostos: um de que a transferência monetária para famílias pobres possibilita a essas famílias tirarem seus filhos da rua e de trabalhos precoces e penosos, enviando-lhes à escola, o que permitirá interromper o ciclo vicioso de reprodução da pobreza; o outro é de que a articulação de uma transferência monetária com políticas e programas estruturantes, no campo da educação, da saúde e do trabalho, direcionados a famílias pobres, poderá representar uma política de enfrentamento à pobreza e às desigualdades sociais e econômicas no país. (Silva; Yazbek; Giovanni, 2011) 
Atualmente (2012) o Programa atende mais de 13 milhões de famílias em todo o território nacional nos 5.564 municípios brasileiros. Seu orçamento em 2010 alcançou 0,4 do PIB (11,4 bilhões). As últimas PNADs revelam uma questão essencial: os PTRs não retiram os beneficiários do trabalho. Inúmeros estudos e pesquisas vêm demonstrando que os impactos desses programas assistenciais sobre as famílias mais pobres, sobretudo no Nordeste, é incontestável. Ele significa basicamente mais comida na mesa dos miseráveis e compra de produtos essenciais. ${ }^{21}$

Em 2010, do total de 12,5 milhões de famílias beneficiárias, cerca de 4,3 milhões superaram a linha de extrema pobreza do Programa (R \$ 70 per capital mês) mas, apesar desses avanços o número de pessoas em situação de pobreza no país ainda é muito alto (por volta de 30 milhões) e a taxa de desigualdade continua entre as mais altas do mundo. Também são conhecidos os impactos dos benefícios sociais, como o Bolsa Família ou a aposentadoria rural nas economias locais, especialmente nos pequenos municípios dependentes da agricultura, que em muitos casos constituem as mais significativas fontes de renda a movimentar o mercado interno de bens e serviços essenciais.

Questões problemáticas vêm sendo apontadas no desenvolvimento desses programas, tais como: quais as reais possibilidades de elevarem o nível de escolaridade da população brasileira, de saúde, de nutrição, ou seja, de inserção social da população atendida? Qual sua efetividade enquanto política pública de enfrentamento da pobreza no país? Qual a sustentabilidade

21. Ver, por exemplo:

1. Silva (Coord.), 2008 e Vieira, 2008.

2. Estudo do Ipea (2008) sobre a pobreza e a riqueza nas seis maiores metrópoles urbanas no Brasil identificou que, no período 2003 a 2007, o crescimento produtivo do país foi acompanhado pela melhoria da renda de todas as famílias, registrando a diminuição do número de pobres, sendo que a situação de pobreza e indigência declinou 1/3, passando de 35,0\% em 2003 para 24,1\%, em 2007. O declínio no número de indigentes foi ainda mais significativo, entre 2002 e 2008 (43,8\%) e de 2003 a 2008 (48,3\%). In: Silva e Yazbek, 2012.

3. Outro estudo do Ipea (2012) sobre o panorama da pobreza, desigualdade de renda e políticas públicas no mundo e no Brasil, verificou que no Brasil, entre 1995 e 2008, a queda média anual da taxa nacional de pobreza absoluta (até meio salário mínimo per capita) foi $-0,8 \%$ ao ano e a taxa anual, no período 2003-2008, de -3,1\%, enquanto a taxa nacional de pobreza extrema (até $1 / 4$ do salário mínimo per capita) foi de $-2,1 \%$ ao ano. $\mathrm{O}$ estudo creditou o declínio na pobreza e na indigência à elevação de gastos sociais após a aprovação da Constituição Federal de 2008, que, em relação ao Produto Interno Bruto, de 13,3\% em 1985, passou para 21,9\%, em 2005. In: Silva e Yazbek, 2012. 
desses programas e seus impactos reais em termos de autonomização das famílias atendidas?

O que se observa é que os programas de transferência de renda focalizados na pobreza e na extrema pobreza revelam, sob a orientação da ideologia neoliberal profundas mudanças nas políticas sociais contemporâneas. A mais significativa delas é a substituição de políticas e programas universais por programas focalizados na pobreza e na extrema pobreza, como se política social fosse "coisa para pobre". Outra constatação é o fato de que esses programas apenas "aliviam" a pobreza, desenvolvendo-se ao largo de políticas econômicas que não se alteram. Ou seja, as determinações estruturais geradoras da pobreza e da desigualdade social não são consideradas, limitando-se essa intervenção a melhorias imediatas nas condições de vida dos pobres, servido tão somente para manter e controlar a pobreza e potencializar a legitimação do Estado. Cria-se um estrato de pobres que se reproduz no nível da sobrevivência, sendo instituída a ilusão de que o problema da pobreza será resolvido pela Política Social (cf. Silva, 2011).

Outro aspecto a ser problematizado é que o direito inalienável ao bem-estar, de todo cidadão de sobreviver com dignidade, é colocado sob a responsabilidade da mulher, que se vê obrigada a administrar a família com valores monetários insuficientes para aquisição da cesta básica (cf. Silva, 2011).

Cabe destacar que o programa apresenta problemas estruturais relevantes que limitam a inclusão de segmentos pobres e reduzem as possibilidades de impactos mais significativos sobre a redução dos índices de pobreza no país. Entre esses problemas estruturais merece destaque a adoção do critério apenas da renda para definição dos pobres e extremamente pobres. Esse critério, além de não considerar a dimensão multidimensional da pobreza, fixa para inclusão uma renda per capita familiar bastante baixa, deixando de fora muitas famílias que vivenciam extremas dificuldades. Ademais, o benefício monetário transferido para as famílias é extremamente baixo, mesmo com reajustes ao longo do tempo, para produzir impactos positivos na ultrapassagem da linha de pobreza por parte das famílias beneficiárias (cf. Silva, 2011).

Sabemos que permanecem na política social brasileira concepções e práticas assistencialistas, clientelistas, "primeiro-damistas" e patrimonialistas. Observamos na rede solidária a expansão de serviços a partir do dever moral, da benemerência e da filantropia, que em si mesmos não realizam direitos. Ainda encontramos em nossas políticas e instituições uma cultura moralista e autoritária que culpa o pobre por sua pobreza. 


\section{A Assistência Social - PNAS /Suas}

Em outubro de 2004, atendendo ao cumprimento das deliberações da IV Conferência Nacional de Assistência, realizada em Brasília em dezembro de 2003, o CNAS - Conselho Nacional de Assistência Social aprovou, após amplo debate coletivo, a Política Nacional de Assistência Social em vigor, que apresenta o (re)desenho desta política, na perspectiva de implementação do Suas — Sistema Único de Assistência Social.

Nessa direção, a Política Nacional de Assistência Social — PNAS buscou incorporar as demandas presentes na sociedade brasileira no que diz respeito à efetivação da assistência social como direito de cidadania e responsabilidade do Estado. Tem como principal objetivo a gestão integrada de ações descentralizadas e participativas de assistência social no Brasil. Essa gestão supõe a articulação de serviços, programas e benefícios, bem como a ampliação de seu financiamento e o estabelecimento de padrões de qualidade e de custeio desses serviços; supõe também a qualificação dos recursos humanos nele envolvidos; a clara definição das relações público/privado na construção da rede socioassistencial; a expansão e multiplicação dos mecanismos participativos, a democratização dos conselhos e a construção de estratégias de resistência à cultura política conservadora; e, por fim, exige que as provisões assistenciais sejam prioritariamente pensadas no âmbito das garantias de cidadania sob vigilância do Estado, cabendo a este a universalização da cobertura e a garantia de direitos e de acesso para os serviços, programas e projetos sob sua responsabilidade. No que se refere à relação com o enfrentamento da pobreza, cabe destacar que a PNAS e o Suas ampliam os usuários alcançados pela política, na perspectiva de superar a fragmentação contida na abordagem por segmentos (como o idoso, o adolescente, a população em situação de rua, entre outros) e de trabalhar com

cidadãos e grupos que se encontram em situações de vulnerabilidade e riscos, tais como: famílias e indivíduos com perda ou fragilidade de vínculos de afetividade, pertencimento e sociabilidade; ciclos de vida; identidades estigmatizadas em termos étnico, cultural e sexual; desvantagem pessoal resultante de deficiências; exclusão pela pobreza e, ou, no acesso às demais políticas públicas; uso de substâncias psicoativas; diferentes formas de violência advinda do núcleo familiar, grupos e indivíduos; inserção precária ou não inserção no mercado de trabalho formal e informal; estratégias e alternativas diferenciadas de sobrevivência que podem representar risco pessoal e social. (PNAS, 2004, p. 27) 
Nesta concepção, evidenciam-se condições de pobreza e vulnerabilidade associadas a um quadro de necessidades objetivas e subjetivas, onde se somam dificuldades materiais, relacionais, culturais que interferem na reprodução social dos trabalhadores e de suas famílias. Trata-se de uma concepção multidimensional de pobreza, que não se reduz às privações materiais, alcançando diferentes planos e dimensões da vida do cidadão. Uma ausência nesse conjunto de necessidades apontadas pela PNAS é a condição de classe que está na gênese da experiência da pobreza, da exclusão e da subalternidade que marca a vida dos usuários da assistência social. Ou seja, é preciso situar os riscos e vulnerabilidades ${ }^{22}$ como indicadores que ocultam/revelam o lugar social que ocupam na teia constitutiva das relações sociais que caracterizam a sociedade capitalista contemporânea. (Silva; Yazbek e Giovanni, 2011) ${ }^{23}$

Face ao desemprego estrutural e à redução das proteções sociais decorrentes do trabalho, a tendência é a ampliação dos que demandam o acesso a serviços e benefícios de assistência social. Assim, os usuários da assistência social tendem a ser trabalhadores e suas famílias, que, mesmo exercendo atividades laborativas, têm suas relações de trabalho marcadas pela informalidade. Em uma conjuntura social adversa, é relevante analisar o significado que os serviços e benefícios sociais passam a ter para os trabalhadores precarizados, que passam a pleitear benefícios sociais, como o Bolsa Família ou a aposentadoria especial.

Diante desse quadro, observa-se que está em curso um processo complexo de redefinição do perfil dos usuários da assistência social, determinado pelas transformações estruturais do capitalismo contemporâneo, que reconfiguram as relações

22. "[...] os conceitos de vulnerabilidade e risco social devem ser poblematizados. Eles não são adjetivos da condição do usuário. A produção da desigualdade é inerente ao sistema capitalista, ao (re)produzi-la produz e reproduz vulnerabilidades e riscos sociais. Essas vulnerabilidades e riscos devem ser enfrentados como produtos dessa desigualdade, e, portanto, requerem uma intervenção para além do campo das políticas sociais. Não se resolve desigualdade com potencialidades individuais ou familiares. Não se trata de 'equipar' os sujeitos, nem de descobrir suas 'potencialidades' como trabalham alguns autores. Trata-se de reconhecer essa desigualdade, de reconhecer que há um campo de atuação importante que atende a necessidades sociais da população e que trabalhá-las como direitos da cidadania rompe com a lógica de responsabilizar o sujeito pelas vicissitudes e mazelas que o capitalismo produz" (Silva; Yazbek e Giovanni, 2011, p. 50)

23. A propósito de problematizar as noções de usuário, território, matricialidade sociofamiliar e trabalho como elementos constitutivos da PNAS, ver o livro de Berenice Rojas Couto et al., 2011. 
entre trabalho e reprodução social, pressionando o Estado a ampliar suas políticas sociais para incorporar novos contingentes populacionais nos serviços e benefícios públicos. (Silva et al., 2011, p. 46)

A construção e implementação do Sistema Único da Assistência Social — Suas (Lei n. 12.435 de 6/7/2011), ${ }^{24}$ como política pública, vem se caracterizando como uma das prioridades para o avanço dessa política.

Para alcançar seus objetivos, propõe-se que a política de assistência social seja realizada de forma integrada e articulada às demais políticas sociais setoriais, para atender às demandas de seus usuários. Isto significa que o destinatário da ação social deve ser alcançável pelas demais políticas públicas. Não podemos esquecer que o sujeito alvo dessas políticas não se fragmenta por suas demandas e necessidades, que são muitas e heterogêneas. Estamos tratando das condições de pobreza que afetam múltiplas dimensões de vida e de sobrevivência dos cidadãos e de suas famílias.

\section{Plano Brasil sem Miséria}

Em maio de 2011 o governo federal lançou mais uma ação no sentido de enfrentar a pobreza: o Plano Brasil sem Miséria, voltado para o enfrentamento da pobreza em uma perspectiva multidimensional.

24. Enquanto sistema cabem ao Suas: a) Ações de proteção básica: prevenção de situações de risco por meio do desenvolvimento de potencialidades e aquisições, e o fortalecimento de vínculos familiares e comunitários. A população-alvo: são famílias e indivíduos que vivem em situação de vulnerabilidade social decorrente da pobreza, privação (ausência de renda, precário ou nulo acesso aos serviços públicos, entre outros) e/ou fragilização de vínculos afetivos-relacionais e de pertencimento social (discriminações etárias, étnicas, de gênero ou por deficiências, entre outras). Os serviços de proteção social básica serão executados de forma direta nos Centros de Referência da Assistência Social — Cras, ou de forma indireta nas entidades e organizações de Assistência Social da área de abrangência dos Cras.

b) Ações de proteção especial: atenção assistencial destinada a indivíduos que se encontram em situação de alta vulnerabilidade pessoal e social. São vulnerabilidades decorrentes do abandono, privação, perda de vínculos, exploração, violência etc. Essas ações destinam-se ao enfrentamento de situações de risco em famílias e indivíduos cujos direitos tenham sido violados e/ou, estejam em situações nas quais já tenha ocorrido o rompimento dos laços familiares e comunitários. Podem ser: de média complexidade: famílias e indivíduos com seus direitos violados, mas cujos vínculos familiares e comunitários não foram rompidos; de alta complexidade: famílias e indivíduos com seus direitos violados, que se encontram sem referência, e/ou, em situação de ameaça, necessitando ser retirados de seu núcleo familiar e/ou, comunitário. 
Dados do IBGE/Censo 2010 identificaram no país um contingente de pessoas em extrema pobreza que totalizou 16,27 milhões de pessoas, o que representa $8,5 \%$ da população total do país. Embora apenas $15,6 \%$ da população brasileira resida em áreas rurais, entre as pessoas em extrema pobreza elas representam pouco menos da metade (46,7\%); o restante $(53,3 \%)$ localiza-se em áreas urbanas, onde reside a maior parte da população - 84,4\%.

O IBGE realizou "um recorte para incluir apenas as pessoas residentes em domicílios que apresentassem maior probabilidade de se encontrar em situação de extrema pobreza. Os critérios adotados para estimar esta parcela da população entre os sem rendimentos foram os seguintes:"

1. Sem banheiro de uso exclusivo; ou,

2. Sem ligação com rede geral de esgoto ou pluvial e não tinham fossa séptica; ou,

3. Em área urbana sem ligação à rede geral de distribuição de água; ou,

4. Em área rural sem ligação à rede geral de distribuição de água e sem poço ou nascente na propriedade; ou,

5. Sem energia elétrica; ou,

6. Com pelo menos um morador de 15 anos ou mais de idade analfabeto; ou,

7. Com pelo menos três moradores de até 14 anos de idade; ou,

8. Pelo menos um morador de 65 anos ou mais de idade.

Conforme dados apresentados no plano Brasil sem Miséria, a absoluta maioria dessas pessoas (70,8\%) é negra (pardas e pretas). Entretanto, chama a atenção a presença de indígenas, apesar de representarem, comparativamente, uma pequena parcela da população em situação extrema pobreza. Os indígenas totalizam 817.963 pessoas no país, sendo que 326.375 se encontram em extrema pobreza, representando praticamente quatro em cada dez indígenas $(39,9 \%)$. Quanto ao sexo, que há uma distribuição homogênea entre homens e mulheres, com leve superioridade da presença feminina (50,5\% contra 49,5\%). Metade dos que vivem na pobreza extrema tem até $19 \operatorname{anos}(50,9 \%)$. As crianças até 14 anos representam cerca de quatro em cada dez indivíduos em extrema pobreza no Brasil (39,9\%). A partir de 2012 estão incluídos no Plano 4,8 mil famílias quilombolas. O Plano vem "puxando" a agricultura familiar comprando as 
sementes crioulas produzidas por pequenos agricultores para distribuir para famílias que vivem em situação de extrema pobreza.

A proposta está direcionada ao enfrentamento da pobreza em sua multidimensionalidade e define como linha de extrema pobreza, renda familiar per capita de até R \$ 70, acima da linha adotada nos Objetivos do Milênio/PNUD (US\$ 1,25) e valor de referência da extrema pobreza do Bolsa Família.

É objetivo geral do Plano: promover a inclusão social e produtiva da população extremamente pobre, tornando residual o percentual dos que vivem abaixo da linha da extrema pobreza.

São seus objetivos específicos: Elevar a renda familiar per capita; ampliar o acesso aos serviços públicos, ações de cidadania e bem-estar social; ampliar o acesso às oportunidades de ocupação e renda por meio de ações de inclusão produtiva nos meios urbano e rural.

O plano vem se desenvolvendo a partir de três eixos, a saber: 1) garantia de renda, 2) inclusão produtiva e, 3) acesso a serviços públicos. Nesses eixos estão sendo buscados a ampliação de oportunidades e o desenvolvimento de capacidades. A busca e a inserção pró-ativas no Bolsa Família será acompanhada de atividades de inserção produtiva no meio urbano (geração de ocupação e renda, micro/empreendedor individual, economia solidária, qualificação e intermediação de mão de obra) e rural (aumento da produção, água, sementes e insumos para todos, acesso aos mercados e autoconsumo).

Como é possível observar, trata-se de um plano que se propõe um enorme desafio, que conjuga ações em três importantes eixos que vão configurar um feixe de mediações, em diversas escalas para penetrar essa trama social configurada pela experiência da pobreza e que não cabe em "modelos" preconcebidos.

\section{Considerações finais: a pobreza como questão política e expressão de relações sociais capitalistas}

Para uma análise em maior profundidade da pobreza brasileira atual, assim como dos mecanismos que vêm sendo desenvolvidos para aliviá-la, as referências principais dizem respeito à forma como concebemos a pobreza e explicamos o contexto onde está inserida. Assim, ao apresentarmos a pobreza como expressão de relações sociais vigentes na sociedade capitalista, é necessário buscar a 
explicação dos processos de acumulação contemporâneos que têm como suporte os interesses do capital financeiro. Como sabemos, trata-se de um contexto caracterizado por mudanças aceleradas, por uma nova sociabilidade e uma abordagem política ainda inscrita na agenda neoliberal.

No Brasil, nesses últimos anos tornaram-se evidentes essas características neoliberais da política social, face às necessidades sociais da população. Há mais de uma década vêm se evidenciando como característica central da política social brasileira sua direção compensatória e seletiva, centrada em situações-limite em termos de sobrevivência e seu direcionamento aos mais pobres dos pobres, incapazes de competir no mercado. Esse é o legado, a herança dos últimos 10 anos: o legado da subordinação do social ao econômico; o social constrangido pelo econômico; o social refilantropizado, despolitizado, despublicizado e focalizado. Efetivamente, no país, o sistema protetivo após a Constituição de 1988,

continua universal na letra da lei. No entanto, ganha cada vez mais foros de unanimidade a ideia de que política social é, por excelência, algum tipo de ação voltada para os excluídos (os pobres) e, por definição, focalizada. Em torno dessa ideia, o debate se tornou insosso, permanecendo restrito ora à fria refutação de dados empíricos, ora a uma morna queda de braço entre opiniões diferentes, prisioneiras, todas da indefectível menção às práticas correntes no país. (Vianna, 2008, p. 3)

Trata-se de um contexto no qual as políticas sociais e especialmente a seguridade social enfrentam profundos paradoxos. Pois se de um lado contam com as garantias constitucionais que pressionam o Estado para o reconhecimento de direitos, por outro se inserem nesse contexto de ajuste às configurações da ordem capitalista internacional, com seu caráter regressivo e conservador, que ameaça o direito e a cidadania, trazendo fortemente a questão da meritocracia e com ela a desuniversalização e a "descidadanização" (cf. Pereira no XIII CBAS 2010).

Outra constatação nesta análise é que no âmbito da legislação voltada para o enfrentamento da pobreza permanece e amplia-se a ação das entidades filantrópicas e socioassistenciais, contexto no qual a pobreza não aparece como expressão da questão social, mas como o "lugar da não política, onde é figurada como dado a ser administrado tecnicamente ou gerido pelas práticas da filantropia. (Telles, 1998, p. 15) Cabe lembrar que esse cenário, que tem como 
expressão maior o crescimento do terceiro setor, vai compor os processos de reestruturação dos sistemas de proteção social e da política social.

Como sabemos, na área da assistência social a parceria histórica com entidades beneficentes resultou em programas fragmentados, na maior parte das vezes desvinculados na realidade onde se instalavam, sem compromisso com espaço público, com programas seletivos e com gestões, quase sempre centralizadoras e pouco participativas. Essa forma de organização criou um caldo de cultura difícil de trabalhar, uma vez que os trabalhos realizados contribuíram muito, para a reiteração da subalternidade da população usuária dos serviços assistenciais.

Diante desse cenário, agravado pela crise global de $2008,{ }^{25}$ embora saibamos que escapa às políticas sociais, às suas capacidades, desenhos e objetivos reverter níveis tão elevados de desigualdade, como os encontrados no Brasil, não podemos duvidar das virtualidades possíveis dessas políticas. Elas são "políticas" e podem ser possibilidade de construção de direitos e iniciativas de "contradesmanche" de uma ordem injusta e desigual. Isso porque esse processo é contraditório e expressa disputas cujos rumos e politização é que permitirão que as atuais políticas de enfrentamento da pobreza se coloquem (ou não) na perspectiva de forjar formas de resistência e defesa da cidadania dos excluídos, ou apenas reiterar práticas conservadoras e assistencialistas.

Assim sendo, na política social brasileira é ampla a agenda de mudanças a ser percorrida em busca de melhorias democráticas e de justiça social. Destacamos:

1. Avançar na perspectiva de universalização da política social (Saúde, Educação), buscando não restringir as políticas sociais à função de combate à pobreza, abandonando suas possibilidades na redução das desigualdades sociais. É preciso superar a perspectiva que, "atribui às políticas sociais um caráter minimalista, focalizado em situações de extrema pobreza, o que as esvazia de seu potencial universalizante e equânime".

2. Buscar construir e assegurar a perspectiva de seguridade social no sistema protetivo da sociedade brasileira. Não podemos esquecer da

25. A crise global de 2008 foi para os especialistas, inédita, que afetou o modo de produção capitalista, uma crise estrutural, que não é exclusivamente financeira embora tenha sido nessa esfera que ela se originou... Sem dúvida, as consequências dessa crise tem um enorme custo social: o aumento da pobreza e do desemprego. 
indissociável relação entre trabalho e seguridade, pois é a partir do reconhecimento do valor do trabalho que se constitui a moderna seguridade social. Essa cobertura é social, não depende do custeio individual direto e objetiva oferecer um conjunto de condições de vida a todos os cidadãos.

3. Integrar as políticas de enfrentamento à pobreza com políticas universais: "conjugação adequada entre as chamadas políticas estruturais voltadas à redistribuição de renda, crescimento da produção, geração de empregos, reforma agrária, entre outros e as intervenções de ordem emergencial, muitas vezes chamadas de políticas compensatórias. Limitar-se a estas últimas quando as políticas estruturais seguem gerando desemprego, concentrando a renda e ampliando a pobreza... significa desperdiçar recursos, iludir a sociedade e perpetuar o problema". Por outro lado, também não é admissível o contrário. Subordinar a luta contra a pobreza à conquista prévia de mudanças profundas nas políticas estruturais representaria a quebra da solidariedade que é dever imperativo de todos perante os milhões de cidadãos hoje condenados à exclusão social e à insuficiência alimentar. (cf. Programa Fome Zero)

Aqui, é importante assinalar que essas políticas interferem nos processos relacionados com a reprodução social da vida, desenvolvendo sua ação em situações sociais que afetam as condições de vida da população em geral e sobretudo dos setores mais empobrecidos da sociedade, objetivando interferir nessas condições sob múltiplos aspectos. Podem produzir resultados concretos nas condições materiais, sociais e culturais da vida de seus usuários, em seu acesso e usufruto de políticas sociais, programas, serviços, recursos e bens, em seus comportamentos, valores, seu modo de viver e de pensar, suas formas de luta e de participação democrática, sua organização, suas práticas de resistência.

Esses desafios nos interpelam "diretamente quando fazemos (ainda?) a aposta em uma cidadania ampliada" e quando buscamos reverter a figura do pobre como não cidadão. Tarefa difícil, que esbarra na herança perversa de uma pobreza persistente e naturalizada, em uma sociedade cada vez mais desigual.

Temos aí um papel de partejar o novo, construir resistências, construir hegemonia, enfrentar as sombras que mergulham os subalternizados de nossa 
sociedade. É preciso politizar e dar visibilidade aos interesses dessas classes... Estamos cumprindo? Não basta a alta qualidade técnica de nosso trabalho, pois corremos o risco de ser bons gestores, despolitizados.

Tarefa difícil construir o político na política social. Construir hegemonia. Construí-la supõe criar "uma cultura que torne indeclináveis as questões propostas pela população com a qual trabalhamos", que nos comprometa e responsabilize mais que isso nos obrigue...

Para isso é necessário nos desvencilhar de certas determinações e de certos condicionamentos impostos pela realidade mesma em que estamos inseridos e de algum modo limitados por eles. Estamos no olho do furacão... E, embora saibamos que escapa às políticas sociais, às suas capacidades, desenhos e objetivos reverter níveis tão elevados de desigualdade, como os encontrados no Brasil, não podemos duvidar das virtualidades possíveis dessas políticas. Elas, por serem contraditórias, podem ser possibilidade de construção de direitos e iniciativas de "contradesmanche" de uma ordem injusta e desigual.

Recebido em 13/4/2012 - Aprovado em 20/4/2012

\section{Referências bibliográficas}

ADORNO, Sergio. A gestão filantrópica da pobreza urbana. São Paulo em Perspectiva. Revista da Fundação Seade, São Paulo, v. 4, n. 2, abr./jun. 1990.

ARAÚJO, Cleonice Correia. Pobreza e programas de transferência de renda: concepções e significados. São Luís: Edufama, 2009.

CASTRO, Jorge Abrahão; RIBEIRO, José Aparecido. As políticas sociais e a Constituição de 1988: conquistas e desafios. In: IPEA. Políticas sociais: acompanhamento e análise vinte anos da Constituição federal. Brasília: Ipea, 2009. v. 17.

COSTA, Suely Gomes da. Pau pra toda obra. Reprodução da força de trabalho e do padrão natural de pobreza, Brasil, século XVI a XIX. Comunicação apresentada no I Seminário dos Países do Cone Sul sobre Políticas Sociais, Propostas e Práticas. Porto Alegre: ICWS, 1990. COUTO, Berenice Rojas. O direito social e a assistência social na sociedade brasileira: uma equação possível. São Paulo: Cortez, 2004. 
COUTO, Berenice Rojas et al. O Sistema Único de Assistência Social no Brasil: uma realidade em movimento. São Paulo: Cortez, 2011.

DI GIOVANNI, G. Sistemas de proteção social: uma introdução conceitual. In: Reforma do Estado. Políticas de Emprego no Brasil. Campinas: Unicamp, 1998.

FAGNANI, E. Ajuste econômico e financiamento da política social brasileira: notas sobre o período 1993-1998. Economia \& Sociedade, Campinas, Unicamp, n. 13, 1999.

. Politica social no Brasil (1964-2002): entre a cidadania e a caridade. Tese (Doutorado) - Unicamp, Campinas, 2005.

FLEURY, Sonia. Estado sem cidadãos: seguridade social na América Latina. Rio de Janeiro: Fiocruz, 1994.

IAMAMOTO, Marilda. Relações sociais e Serviço Social no Brasil: esboço de uma interpretação histórico/metodológica. 10. ed. São Paulo: Cortez, 1995.

. Serviço Social em tempo de capital fetiche: capital financeiro, trabalho e questão social. São Paulo: Cortez, 2007.

IANNI, Octavio. A questão social. In: São Paulo em Perspectiva. São Paulo: Seade, jan./ mar. 1990.

IPEA. Pobreza e riqueza no Brasil metropolitano. Brasília, Comunicação da Presidência n. 7, ago. 2008.

. Pobreza, desigualdade e políticas públicas. Brasília, Comunicação da Presidência n. 38, jan. 2010. Disponível em: <www.ipea.gov.br>.

IVO, Anete Brito Leal. A reconversão da questão social e a retórica da pobreza nos anos de 1990. In: CIMADAMORE, Alberto; DEAN, Hartley; SIQUEIRA Jorge (Orgs.). Pobreza do Estado: reconsiderando o papel do Estado na luta contra a pobreza global. Buenos Aires: Clacso, 2006.

. Viver por um fio: pobreza e política social. São Paulo: Annablume; Salvador: CRH/ UFBA, 2008.

MARTINS, José de Souza. O massacre dos inocentes: a criança sem infância no Brasil. São Paulo: Hucitec, 1991.

MESTRINER, Maria Luiza. O Estado entre a filantropia e a assistência social. São Paulo: Cortez, 2001.

MISHRA, Ramesh. O Estado providência na sociedade capitalista. Oeiras: Celta, 1995.

SARTI, Cyntia Andersen. A família como espelho: um estudo sobre a moral dos pobres. São Paulo: Cortez, 2003. 
SATRIANI, Luigi Lombardi. Antropologia cultural e análise da classe subalterna. Trad. de Josildeth Gomes Consorte. São Paulo: Hucitec, 1986.

SEN, Amartya. Desenvolvimento como liberdade. São Paulo: Companhia das Letras 2000. . Desigualdade reexaminada. Rio de Janeiro: Record, 2001.

SILVA, Maria Ozanira da Silva e. Pobreza, desigualdade e política pública: caracterizando e problematizando a realidade brasileira. Revista Katálysis, Florianóplois, v. 13, n. 2, jul./ dez. 2010.

(Coord.). O Bolsa Família: no enfrentamento à pobreza no Maranhão e Piauí. São Paulo: Cortez; Teresina: UFPI, 2008

; YAZBEK, Maria Carmelita. Políticas públicas de trabalho e renda no Brasil contemporâneo. São Paulo: Cortez, 2012.

; YAZBEK, Maria Carmelita; GIOVANNI, Geraldo. A política social brasileira no século XXI: a prevalência dos programas de transferência de renda. 5. ed. São Paulo: Cortez, 2011.

SPOSATI, Aldaíza. Vida urbana e gestão da pobreza. São Paulo: Cortez, 1988.

. Cidadania ou filantropia: um dilema para o CNAS. Cadernos do Núcleo de Seguridade e Assistência Social da PUC-SP. São Paulo, ago. 1994.

. Assistência Social, políticas públicas e participação pós-Constituição de 1988. Cadernos Abong, série especial, out. 1995.

TELLES, Vera da Silva. A cidadania inexistente: incivilidade e pobreza, um estudo sobre trabalho e família na grande São Paulo. Tese (Doutorado) - Departamento de Sociologia da USP, 1992. n. 19, 1993.

. Pobreza e Cidadania. Dilemas do Brasil contemporâneo. Caderno CRH, Salvador, . No fio da navalha: entre carências e direitos. Notas a propósito dos Programas de Renda Mínima no Brasil. Revista Polis. São Paulo, 1998.

. Direitos sociais. Afinal do que se trata? Belo Horizonte: Ed. UFMG, 1999.

. Pobreza e cidadania. São Paulo: Editora 34, 2001.

VERDÈS-LEROUX, Jeannine. Trabalhador social: prática, habitus, ethos, formas de intervenção. Trad. de René de Carvalho. São Paulo: Cortez, 1986.

VIANNA, Maria Lucia Teixeira Werneck. A americanização (perversa) da seguridade social no Brasil: estratégias de bem-estar e políticas públicas. Rio de Janeiro: Ed. Revan: Ucam, Iuperj, 1998. 
VIEIRA, Ana Cristina de Souza. Declínio da desigualdade no Brasil. In: ; AMARAL, Maria Virgínia Borges. Trabalho e direitos sociais: bases para a discussão. Maceió: Ufal, 2008.

WANDERLEY, Luiz Eduardo W. A questão social no contexto da globalização: o caso latino-americano e caribenho. In: CASTEL, Robert; WANDERLEY, Luiz Eduardo W. Desigualdade e a questão social. 3. ed. São Paulo: Educ, 2008.

YAZBEK, Maria Carmelita. A assistência social na cidade de São Paulo. São Paulo: Instituto Polis, PUC-SP, 2004. (Observatório dos Direitos do Cidadão: acompanhamento e análise das políticas públicas da cidade de São Paulo.)

. Classes subalternas e assistência social. 7. ed. São Paulo: Cortez, 2009.

. Voluntariado e profissionalidade na intervenção social. Revista de Políticas Públicas, v. 6, n. 2. São Luís, 2002.

Estado, Políticas Sociais e Implementação do SUAS. In: SUAS: configurando os eixos de mudança. Brasília, MDS, IEE, 2008.

ZALUAR, Alba. A máquina e a revolta: as organizações populares e o significado da pobreza. São Paulo: Brasiliense, 1985. 